\title{
Philosophical Meaning of Zapin Pecah Dua Belas Dance In Pelalawan District, Riau Province
}

\author{
Dewi Susanti ${ }^{1}$ \\ \{dewisusanti01@edu.uir.ac.id ${ }^{1}$ \} \\ ${ }^{1}$ Universitas Islam Riau, Indonesia
}

\begin{abstract}
Zapin is one of Malay dance art genres that still exists and develops on the coast of the archipelago. Generally, Zapin Dance is dominant tradition of movement by footwork following the rhythm of the drum. The movements are dynamic and tend to be rough and the rhythm of the music is strong. The dancers and musicians are all male and generally consists of back and forth and rotating movements. The repertoire of songs generally not only speaks Arabic but also speak Malay. Zapin Peca Dua Bekas dance talks about the existence of zapin pecah dua belas, from that existence which covers the historical aspects, social aspects, religious aspects, artistic aspects and traditional aspects. Method used is descriptive analysis. In Zapin Pecah Dua Belas dance jfrom the existentialism of Zapin Pecah Dua Belas dance, it has reached national and international stages. Philosophy addresses everything that is in nature which is often said to be general philosophy. while limited philosophy is philosophy of science, philosophy of education, philosophy of art, philosophy of religion, and Ontology of Philosophical Knowledge, Epistemology of Philosophical Knowledge, Axiology of Knowledge Philosophy, etc.
\end{abstract}

Keywords: philosophy, meaning, Zapin Pecah 12, Riau province

\section{INTRODUCTION}

Zapin is a type of traditional dance that found in the Malay community, such as in Bengkalis, Siak, Pelalawan, and most parts in Riau, especially in coastal areas. Traditional zapin in Riau Province has differences, one of which is the difference in ethnic cultural backgrounds that support it. Although different from one another, there are similarities and influences [1]. Zapin is one of the Malay dance art genres that lives and develops on the coast of the archipelago. In general, Zapin Dance is a very dominant tradition of movement with footwork following the rhythm caused by the sound of the drum. The movements are dynamic and tend to be rough and the rhythm of the music is strong. Generally consists of back and forth and rotating movements, the dancers and musicians are all male. The repertoire of songs generally speaks Arabic, although there are some who speak Malay. The meaning of Zapin is a dance rhythm that is popular in coastal areas of Indonesia originating from the Arab community, and is a part of entertainment associated with Islam [2]. The typical arrangement of instruments is lut, accordion and marwas. The couple of dancers are men with men, so that was exemplified by a group that was examined by the conversion of Betawi traditional arts in 1985 at the Kwitang mosque. 
Zapin Pecah Dua Belas dance has 12 varieties, namely: (1) Worship Three / Broken One, (2) Broken Back, (3) Middle Broken, (4) Side Broken, (5) Broken Base, (6) Middle Sut, (7) Broken Middle, (8) Broken Eight / Elbow Triple Elbow, (9) Broken Edge, (10) Broken 10, (11) Hanging Hanging, (12) Throne. Zapin Pecah Dua Belas is also accompanied by a musical instrument accompanied by two or three drum marwas so as to form an ensemble. Gambus as accompaniment of Zapin functions as a regulator of the tempo, accompaniment of motion, and create an atmosphere.

According to Herusatoto philosophy means thinking by using reason as deeply as possible with full responsibility, following methods and systems that are orderly, orderly to reveal the mysteries of the problems we want to solve, after which general and universal conclusions are sought [3].

An art cannot be separated from the origin of culture and values, as well as the philosophy that is owned by the people of the arts region originates. Like a philosophy that is formed in the civilization of society that produces an art. A dance for example, has a basis of origin and value that originates from culture and society [4].

In the lives of everyday people often found the work of art and symbols both consciously and unconsciously, it is known the intent and purpose of these things. As for the artwork, it contains profound meanings in accordance with the interpreter or user interpretation [5]. These meanings are included or presented based on a traditional cultural value and philosophy of the local community. This meaning can be a message, as well as values that can also be owned in a form of art. In a work of art especially dance, one of which can be a conduit of that meaning is through various media through music, costumes, and symbols of motion.

The meaning is an inseparable part of semantics and always inherent from the things we say. Understanding of the meaning itsself is very diverse. According to Ullman argues that meaning is the relationship between meaning and understanding. In this case Ferdinand de Saussure. In dance works, not only dance elements that become important elements in their cultivation, there are other elements of concern for both dancers and dance stylists [6]. These elements are Wiraga (raga), Wirama (rhythm) and Wirasa (sense). These three elements merge into one form a harmonious dance. All three must be done in harmony. If one of these elements is not done well, the dance will look less beautiful.

\section{METHOD}

According to Iskandar methodology is knowledge that must be possessed by researchers. Without the knowledge of methodology the researcher is certainly not able to carry out scientific research. Therefore, it is very minimal to find experts or experts in research outside of college because the research is related to problem discovery, making research designs, collecting data, mastering theory, analyzing data and requiring funds, time. Opportunities for the needs of social sciences or educators. In this study, researchers used descriptive analysis method based on qualitative data, because the data obtained were data found directly in the field, namely the Meaning of Philosophy Contained in Broken Zapin Dance 12 in Pelalawan Regency, Riau Province.

\section{RESULT AND DISCUSSION}

\subsection{Philosopical Meaning of Zapin Pecah Dua Belas Dance.}

In the context of Malay culture the term zapin implies one genre of art which includes: (a) text, (b) dance, (c) music, which is rooted in Yemeni civilization in West Asia, and contains 
values of Islamic teachings. The text element zapin, in Malay culture consists of Arabic, a mixture of Malay and Arabic, and the Malay language itself. This text is compiled based on pantun or free text lines that support the theme. The zapin text can however be grouped into the type of song, because it follows the existing melody. This text is delivered explicitly, but not infrequently it is also conveyed implicitly [7]. Zapin song texts have cultural meanings, which can only be understood based on empirical experience of culture, especially Malay culture.

The philosophy of meaning that is intended to be communicated in the Zapin Pecah Dua Belas Dance is that anyone who wants to make an offering must pay homage to the audience in accordance with the guidelines of Malay culture. Then in the offerings the players are bound by dance norms outlined by Malay customs and culture. But besides that as human beings we also need to express polite freedom, which is given at tahtim and tahto (tahtum). At the end of the offering the music plays tahtim or tahto as a coda offering.

\subsection{Movement of Zapin Pecah Dua Belas Dance}

In the Zapin Pecah Dua Belas dance, there are various aspects to be communicated. Zapin Pecah Dua Belas dance generally consists of 12 varieties and each variety is interconnected. These varieties, namely: Worship Three, Broken Back, Broken Middle, Side Broken, Broken Base, Middle Bro, Half Broken, Broken 8 / Triple Elbow, Broken Edge, Broken Ten, Hanging Sut, Throne or Tahtum. Where the first variety is broken down into the second range or related to the second variety. The second variety is broken down into the third variety or related to the third variety, and so on up to the twelfth variety which is closed with the Tahtum or the Worship [8]. Zapin Dance Breaks Twelve generally uses a lot of foot movements, while hand movements are less highlighted. The position of the left hand forms an elbow and is held together on the left side of the chest and the hand is held parallel to the chest. The position of the right hand moves according to the footwork that is moved.

a. Broken one / worship three

The meaning of worship three / rupture one is to give greetings or respect to guests who have come at the wedding or at the welcoming ceremony so that guests can feel respected and intend to be inferior and respectful. This motion is a motion that is displayed at the beginning of the Zapin Dance breaks 12. This motion is carried out 2 times, namely at the beginning and end of the Zapin Dance. This motion is done in 8 counts per 1 time.

\section{b. Back Broken}

The meaning of this broken back movement is about movements that require permission to pass or pass before the guest, by lowering the position of the body.

\section{c. Middle Broken}

This movement means prioritizing fairness and patience with balance so that the audience can understand the movement. This motion is done twice, namely Shut forward and Shut backwards. This motion is done in 16 counts per 1 time.

\section{d. Side Broken}

This movement means dynamic life with community in order to see life. This motion is done after the free movement 2 times before is motion Shut back and forth. This motion is carried out 2 times namely forward and backward. This motion is done in 16 counts per 1 time. 


\section{e. Base Broken}

This movement means that determination and skill in facing trials. This motion is carried out after the previous two free movements are side burst motion.

\section{f. Middle Sut}

This meaningful movement about living in a community helps each other and works together with each other so that they can unite.

\section{g. Middle Broken}

This movement means Concern for the environment in the community. This motion is carried out after the previous two free movements are half sutured and the base breaks.

\section{h. Eight Broken}

The meaning of the breaking movement of eight or elbows is about the values of life adopted by the local community, in order to be able to help each other. This movement is carried out between the movements of the other, there are as many as 1 time or as much as 2 times.

\section{i. Edge Broken}

The meaning of the breaking edge movement is the same as the meaning of breaking up the elbow or the elbow that is a life and helping each other. This motion is carried out between the movements of others, there are as many as 1 time or as many as 2 times

\section{j. Ten Broken}

This meaningful movement about living in a community helps each other and cooperates with each other so that they can unite, and strengthen the fellowship between people from one another.

\section{k. Hanging}

This movement means that determination and skill in facing trials. This motion is carried out after the previous free movement 2 times

\section{l. Throne / tahtum}

The meaning of the throne / tahtum is a movement that states that dance or offerings are finished and can enjoy the next event. This gesture of greeting is not a parable of worshiping the guests present, which has often been misunderstood, but a symbol of respect and respect

\subsection{Philosphical Meaning}

The philosophy of meaning contained in Zapin Pecah Dua Belas dance movement is one of the customs and culture of the lives of Malay people who do not want to leave their siblings, and also share the burden and pleasure with their siblings. Zapin dance Breaks the Twelve is certainly inseparable from the Islamic values embraced by the people[9].

The assessment of the beauty of traditional dance movements is often influenced by social, ethnic, emotional, religious, and local beliefs. In dancing Tandak dances and zapin dance for example, couples of male and female dancers move close together, but may not touch each other. In Malay dance it is also distinguished by the ideal dance movements of men and 
women's dances, female dancers should emphasize gentle posture and movements, while male dancers with dashing gestures and gestures. In zapin, male dancers dance at a faster tempo than the movements of female dancers.

\subsection{Musical tools}

Zapin Dance Broken Twelve is accompanied by traditional Malay music. The musical instrument in the implementation of the Zapin dance Broken Twelve is Gambus and Marwas.

\subsection{Dramatic design Zapin Pecah Dua Belas Dance.}

The dramatic design of the Zapin Pecah Dua Twelve Dance is in the form of a single cone design because in this dance there is only one of the highest climax of the entire dance series. For more details, the author describes the dramatic design form in the Zapin Pecah Dua Twelve Dance as follows:

The meaning of the philosophy of this dramatic design is about expression to convey a problem that exists in the environment or community environment.

\subsubsection{Dynamic of Zapin Pecah Dua Belas Dance}

Based on the results of the author's analysis, the dynamics of the Twelve Zapin Dance is on the variety of one dancer performing a low level sitting position, then the music sounds male dancers and female dancers change their level to a high level. In a variety of two dancers doing walking movements with a moderate level, medium and medium volumes of motion, but at counts of five and six there are changes in tempo to slow. Male and female dancers in the three types do not move with moderate levels, moderate and medium tempo movements. So that in the range of three there is no dynamic. Likewise, in the range of six there are no tempo changes, nor levels. In a variety of five there are dynamics, namely by making a change of tempo from moderate to fast tempo, the movement is done on a count of four to count five [10]. The philosophy of meaning in the results of the dynamics of the Zapin Dance Breaks the Twelve above, the dynamics of the dance can be seen from the changes in the tempo of the dance, the speed of the dance, changes in motion levels, changes in motion volume, and also the motion pressure from moderate to strong. The dynamics of motion are also influenced by changes in the music seen from changes in tempo slowly, medium and fast.

\subsubsection{Theme of Zapin Pecah Dua Belas Dance}

The philosophy of the meaning found in the field, which is about the theme found in the performance of the Zapin Dance Broken Twelve, is the social life of the Pelalawan community, namely as a welcoming dance and also entertainment. The theme of the Zapin Dance Broken Twelve is the social life of the Pelalawan community, this dance as a welcoming dance for royal guests and royal entertainment in the past, now it has become a folk dance that can be used to welcome guests and entertainment to officials and the public at generally.

\subsubsection{Design of Zapin Pecah Dua Belas Group}

The philosophy of meaning of the group design at the Zapin Pecah Dua Belas dance uses the unison or simultaneous, balanced or balanced design. There are no broken movements or split, alternate or alternating and canon or alternately. For more details, it is illustrated in the form of a floor pattern that is unison or simultaneous, balanced or balanced

On the second floor pattern, male dancers are in the right and left rear corners, and female dancers are in the front position by forming a rectangular floor pattern. The pattern of this 
floor remains until the end of the dance, only there is a change in direction towards the eight dancers.

\subsubsection{Custom and accecories in Zapin Pecah Dua Belas Dance}

a. Custom and accecories for women dancers

Consisting of a long sleeved Malay shirt or a green Malay curly shirt combination on the neck and arms in red. The skirt is red in color, and uses songket cloth as a side cloth that is attached to the waist and uses a long bengkung or cloth wrapped around the waist. Flower shape. Wear beautiful makeup according to the color of the clothes worn by dancers, then hair is bun and wear accessories such as large flowers and hairpin.

The philosophy of the whole meaning of the Zapin Dance Breaker Twelve costume is an embodiment of obedience to religious teachings that aims to maintain the dignity of a woman by using clothes that are closed and not body shape, which is in accordance with Malay customs that are based on the books of Allah.

\section{b. Custom and accecories for men dancers}

Consisting of long sleeved Malay shirt and red trousers. Wear songket as a side cloth that is attached to the waist or abdomen. Then wear a cap decorated with brooches. Besides that, the bada of her shirt was also decorated with a silver brooch shaped like a flower. The makeup used for male dancers is dashing makeup.

The philosophy of the whole meaning of the Zapin Dance Breaker Twelve costume is an embodiment of obedience to religious teachings which aims to maintain the dignity of a man by using clothes that are closed and not body shape, which is in accordance with Malay customs which are based on the books of Allah.

\subsubsection{Performing of Zapin Pecah Dua Belas Dance}

Performing occurs along with dance, because dance requires space and place. Other equipment is also needed which looks alive and attractive. Based on the author's observation, the Zapin Pecah Dua Belas dance shows, for wedding parties and government events.

\subsubsection{Aesthetic of Zapin Pecah Dua Belas Dance}

Zapin Pecah Dua Belas dance as an art product, produces a beauty. The beauty in this dance can be seen objectively and subjectively. But in this study the author focuses more on objective beauty.

\subsection{Unity of Zapin Pecah Dua Belas Dance}

Unity, totality (Unity) states intact in diversity, so that each work of art contains only elements that need and mutually have mutual relations. Unity in the dance of Zapin Pecah Dua Belas dance is clearly seen as a whole and interrelated relationship between the elements of dance. Starting from the movements of the dance, the music, the dramatic design, the dynamics, the design of the group, the themes, the costumes and makeup to the stage, there are elements that have mutual relations, which cannot be separated from one element to another.

\subsection{Harmony of Zapin Pecah Dua Belas Dance}

Harmony is harmony between the elements of art with one another, resulting in the beauty of harmony. In this Zapin dance, it can be clearly seen the harmony starting from the dance movement, namely the variety of Zapin dance formed from the variety of one into the variety of two, the variety of two into the variety of three so on until finally forming into a variety of 
twelve. The formation of the variety of dance, of course, produces harmony or beautiful harmony.

\subsection{Balancing in Zapin Pecah Dua Belas Dance.}

The principle of equilibrium, refers to similarity or opposition from opposing elements but requires each other, thus creating balance. In balance can be seen through the dance elements, including: Motion, Power, Rhythm / Rhythm, Space.

\section{CONCLUSION}

The meaning of the movement originating from the tradition of upholding the deity of the people has a diversity of cultures and also the religious community, Riau region is not only filled by the original community, namely the ethnic Malays, but there are also migrants from outside the Riau region. Zapin Pecah Dua Belas Dance is accompanied by traditional Malay music. The musical instrument in the implementation of the Zapin Pecah Dua Belas is Gambus and Marwas. Gambus functions as a melody, and Marwas functions as a tempo regulator. The dramatic design of the Zapin Pecah Dua Belas Dance is in the form of a single cone design because in this dance there is only one of the highest climax of the entire dance series. The dynamics of the Zapin Pecah Dua Belas dance are realized by various techniques and levels, for example low level, medium level and high level so that it gives birth to a dynamic motion that varies and according to the tempo of the music being played.

The group design on the Zapin Pecah Dua Belas dance uses the unison or simultaneous, balanced or balanced design. There are no broken movements or split, alternate or alternating and canon or alternately. the performance of the Zapin Pecah Dua Belas dance performance is adjusted to the location of the event and it is estimated that space or distance before the dance performance begins. There is no stage size requirement that is used because this dance is an entertaining dance and can be displayed on a large stage or stage as it is the five beauty requirements that must be met, namely: a) unity, totality (unity); b) harmony, harmony (harmony); c) symmetry (symmetry); d) balance (balance); e) opposition, resistance, contradiction (contrast). In this study there are only three conditions that are met to discuss the aesthetics of zapin dance, among others: a) unity, totality (unity); b) harmony, harmony (harmony); c) balance (balance).

\section{REFERENCES}

[1] Harma, A. R., Desfiarni, D., \& Susmiarti, S. Faktor Penghambat Perkembangan Tari Zapin Melayu di Kota Batam. Jurnal Sendratasik, 6(1), 7-14. 2017.

[2] Sarita, S., Isjoni, I., \& Kamaruddin, K. Sejarah Perkembangan Tari Zapin Desa Meskom Kecamatan Bengkalis Kabupaten Bengkalis. Jurnal Online Mahasiswa Fakultas Keguruan dan Ilmu Pendidikan Universitas Riau, 2(2), 1-10. 2014.

[3] Indah, I. Y., Ediwar, E. E., \& Martion, M. M. Estetika Tari Zapin sebagai Sumber Penciptaan Karya Kaki-kaki. Bercadik: Jurnal Pengkajian dan Penciptaan Seni, 1(1). 2017.

[4] Zulfahmi, M. Interaksi Dan Inter Relasi Kebudayaan Seni Melayu Sebagai Sebuah Proses Pembentukan Identitas. Ekspresi Seni, 18(2), 307-323. 2016.

[5] Ganap, V. Membangun Industri Kreatif Di Maluku Melalui Pendidikan Seni. Harmonia: Journal of Arts Research and Education, 12(1). 2012. 
[6] Helsa, Y., \& Hartono, Y. Designing reflection and symmetry learning by using math traditional dance in primary school. Journal on Mathematics Education, 2(1), 79-94. 2014.

[7] Hegarini, E., \& Syakur, A. Indonesian traditional dance motion capture documentation. In 2016 2nd International Conference on Science and Technology-Computer (ICST) (pp. 108-111). IEEE. 2016.

[8] Harnish, D. "Digging" and" upgrading": Government efforts to" develop" music and dance in Lombok, Indonesia. Asian Music, 38(1), 61-87. 2007.

[9] Adnan, N. Character Building through Traditional Dance as Developing Identity Belongings: A Study of Indonesia-Malaysia. In International Conference on Languages and Arts (pp. 340-346). 2014, November.

[10] Annisa, W., Satriati, A., \& Wiharsih, R. Educational Values in Choreography Analysis of Rentak Bulian Dance in Riau Province. In International Conference on Art and Arts Education (ICAAE 2018). Atlantis Press. 2019. 